\title{
Correlation between Serum Uric Acid Level and Severity of Coronary Artery Stenosis in Patients with Acute Coronary Syndrome
}

\author{
Diding Heri Prasetyo, ${ }^{1,2}$ Sally Aman Nasution, ${ }^{2}$ Idrus Alwi, $^{2}$ Murdani Abdullah $^{2}$ \\ ${ }^{1}$ Department of Internal Medicine, School of Medicine, Universitas Sebelas Maret/Dr. Moewardi Hospital, \\ Surakarta, Indonesia, ${ }^{2}$ Department of Internal Medicine, School of Medicine, Universitas Indonesia/ \\ Dr. Cipto Mangunkusumo Hospital, Jakarta, Indonesia
}

\begin{abstract}
Acute coronary syndrome (ACS) is a life-threatening disease which remains a source of high morbidity and mortality despite advances in treatment. The relationship between serum uric acid (SUA) level and ischemic heart disease abides controversial and still has not been established as a cardiovascular risk factor. The cooperative interaction between those two factors is not fully understood. Prior epidemiological evidences of the causal relationship is still argumentative. There were various studies using the same methods yet the outcome were different. This study aims to conduct a meta-analysis to synthesize the results of recent studies in order to obtain data quantitatively and also accurately. Systematic study follows the guidelines for preferred reporting items for systematic reviews and meta-analysis (PRISMA), tracing studies published in vulnerable periods from January 2010 to May 2020. The Cochrane Library, Ebsco, Medline/PubMed, ProQuest and Science Direct are sources of published studies. Meta-analysis was conducted to synthesize the associations between SUA level and severity of coronary artery stenosis, using random effect model to account for possible study heterogeneity. Heterogeneity was assessed using $\mathrm{I}^{2}$, and the meta-analysis was performed using Comprehensive Meta Analysis Version 3 (CMA3) software. Five studies ( $\mathrm{n}=601$ patients) identified a correlation between serum uric acid levels and Gensini scores $(\mathrm{r}=0.548 ; \mathrm{p}<0.001)$ in ACS patients. Heterogeneity bias was found in the analysis, whereas publication bias was not found. Conclusion, severity of coronary artery stenosis in patients with ACS is positively correlated with serum uric acid levels.
\end{abstract}

Keywords: Acute coronary syndromes, Gensini score, uric acid

\section{Hubungan Kadar Asam Urat Serum dengan Keparahan Stenosis Arteri Koroner pada Pasien Sindrom Koroner Akut}

\begin{abstract}
Abstrak
Sindrom koroner akut (SKA) adalah gangguan yang mengancam jiwa yang tetap menjadi sumber morbiditas dan mortalitas yang tinggi meskipun ada kemajuan dalam pengobatan. Hubungan antara asam urat serum dengan penyakit jantung iskemik masih kontroversial dan belum ditetapkan sebagai faktor risiko kardiovaskular. Interaksi kooperatif antara keduanya tidak sepenuhnya dipahami. Beberapa bukti epidemiologis hubungan kausal tersebut masih kontroversial. Sering sekali penelitian dengan kasus yang sama dan menggunakan metode yang sama tetapi hasilnya berbeda. Penelitian ini bertujuan melakukan meta analisis untuk mensintesis hasil-hasil penelitian yang berbeda tersebut agar diperoleh data baru yang bersifat kuantitatif dan lebih akurat. Telaah sistematis mengikuti pedoman preferred reporting items for systematic reviews and meta-analyses (PRISMA), dengan menelusuri studi yang dipublikasikan dalam rentan waktu dari Januari 2010 hingga Mei 2020. Cochrane Library, Ebsco, Medline/ PubMed, ProQuest, dan Science Direct adalah sumber dari studi yang dipublikasikan. Meta-analisis dilakukan untuk mensintesis korelasi antara kadar asam urat serum dan keparahan stenosis arteri koroner, menggunakan model efek acak untuk menjelaskan kemungkinan heterogenitas penelitian. Heterogenitas dinilai menggunakan $\mathrm{I}^{2}$, dan meta analisis menggunakan perangkat lunak Comprehensive Meta Analysis Version 3 (CMA3). Lima studi ( $\mathrm{n}=601$ pasien) diidentifikasi didapatkan korelasi antara kadar asam urat serum dan skor Gensini $(\mathrm{r}=0,548 ; \mathrm{p}<0,001)$ pada pasien SKA. Bias heterogenitas ditemukan dalam analisis, sedangkan bias publikasi tidak ditemukan. Simpulan, keparahan stenosis arteri koroner pada pasien dengan SKA berkorelasi positif dengan kadar asam urat serum.
\end{abstract}

Kata kunci: Asam urat, sindrom koroner akut, skor Gensini

Corresponding Author: Diding Heri Prasetyo, Department of Internal Medicine, School of Medicine, Sebelas Maret University/ Dr. Moewardi Hospital, Surakarta, Indonesia. Jl. Kolonel Sutarto No.132, Jebres, Surakarta, Jawa Tengah 57126, Indonesia, Email: didinghapeuns@gmail.com 


\section{Introduction}

Cardiovascular disease (CVD) is a global primary cause of death which accounts for 4.1 million deaths in Europe alone. According to the WHO in 2019, 1.7 million of CVD-related deaths are caused by coronary artery disease (CAD). Acute Coronary Syndome (ACS) has become the primary cause of deaths and disabilities in Asia-Pacific, with more than 5\% mortality in hospitalized patients. ${ }^{1}$ the region still lacks consensus on the best approach to overcoming its specific challenges in reducing mortality from ACS. The Asia-Pacific Real world evIdenCe on Outcome and Treatment of ACS (APRICOT ACS covers a wide variety of clinical conditions, such as angina pectoris (UAP), non-ST elevation myocardial infarction (NSTEMI), dan ST-elevation myocardial infarction (STEMI). ${ }^{2}$

Increased serum uric acid (SUA) level is a risk factor for cardiovascular disease (CVD). An increase in the SUA level is a common finding in patients with hypertension, insulin resistance, obesity, and CVD. However, it is still under debate whether such elevation is an independent predictor of cardiovascular risk or not. Nevertheless, the hypothesis that a reduction in the SUA level could prevent CVD has not been tested. ${ }^{3}$ A meta-analysis study reported that an increase in the SUA level significantly increases mortality and risk of major adverse cardiovascular events (MACE) and severe acute coronary artery diseases. ${ }^{4}$ Escalation in the SUA level correlates with cardiometabolic risks, which play a principal role in the pathophysiology of atherosclerotic formation. Increased uric acid level will increase the occurrence of endothelial dysfunction, oxidative stress, local inflammation, and insulin resistance, as well as inducing the proliferation of vascular smooth muscle cells that leads to vasoconstriction. This condition will trigger the development of atherosclerotic plaques, emphasizing its important role in the pathophysiology of cardiovascular disease. ${ }^{5}$

Acute coronary syndrome often reflects a degree of damages to the coronary arteries by atherosclerosis, plaque rupture, thrombosis, and inflammation. The SUA level in patients with ACS is higher than those with chronic coronary syndrome (CCS). As a result, many studies show a positive correlation between an increment in SUA levels and stenosis coronary artery score in patients with ACS. ${ }^{6,7}$ number of diseased vessels, critical lesions and total occlusions on coronary angiogram. Results: Mean age of normouricemic group $(n=59$ The SUA level has a positive correlation with Gensini score and Syntax score in patients with CAD when compared to control. Furthermore, the SUA level associates with the amount of coronary artery atherosclerosis in patients with ACS. ${ }^{8}$ Several studies have analyzed the correlation between hyperuricemia and severity of coronary artery disease by comparing them with normouricemia in ACS patients. However, the hyperuricemia terms have various boundaries and interpretations, causing differences in the results. Until recently, no systematic review on the correlation between SUA level and coronary artery stenosis severity in patients with ACS has been conducted. Hence, this meta-analysis aimed to systematically analyze the correlation between SUA level and coronary artery stenosis severity in patients with ACS.

\section{Methods}

This study is registered with PROSPERO, CRD42020210948 and reported by following the recommendation and guideline of the Preferred Reporting Items of Systematic Reviews and Metaanalyses (PRISMA). Two authors independently extracted data from published studies and metaanalysis was conducted using the Comprehensive Meta Analisis version 3 (CMA 3) software.

The authors conducted literature search in Cochrane Library, Ebsco, Medline/PubMed, ProQuest, and Science Direct. Where available, both controlled vocabulary terms and text words (MesH and keywords) were used in the subject component blocks. The search was conducted on studies published in English during the period of 2010 to May 2020. This period was selected to provide a contemporary reflection of relationship between SUA and severity of coronary artery stenosis in ACS patients. Additional studies were identified by searching article reference lists and including grey literature from the first 200 hits on Google Scholar after entering the index term combinations.

Sample was collected using PRISMA approach by applying the following inclusion criteria: (i) literature observed a correlation between two variables or more; (ii) used quantitative approach; (iii) included serum uric acid and coronary artery stenosis severity as research variables; (iv) subjects were patients with ACS; (v) and distinct diagnostic criteria for coronary artery stenosis severity measured with Gensini score was applied. Literature was excluded if it took the form of abstract, a piece from 
DH Prasetyo et al: Correlation between Serum Uric Acid Level and Severity of Coronary Artery Stenosis in Patients with Acute Coronary Syndrome

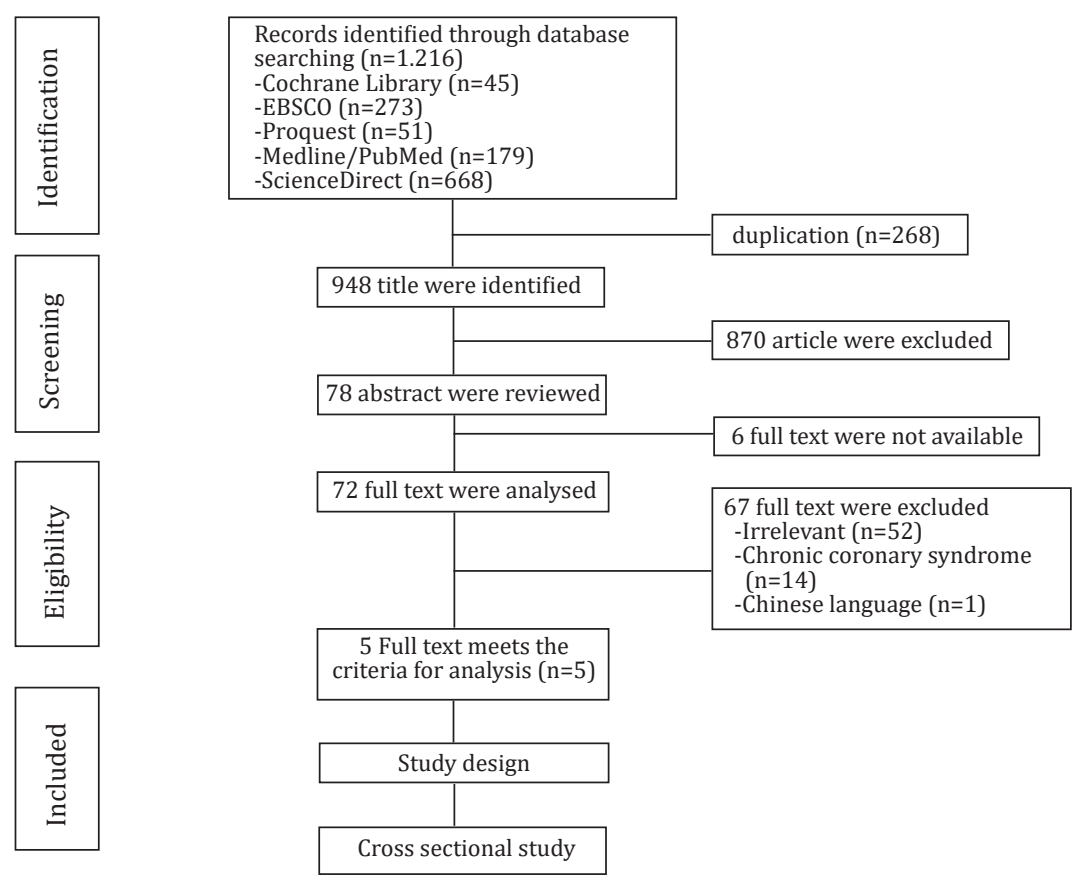

\section{Figure 1 PRISMA Flow Diagram on Study Inclusion and Exclusion and Their Rationale}

book chapters, case reports, bulletin reviews, dissertations or thesis, and non-completed researche

The reviewer independently performed title and abstract screening, data extraction, and risk of bias assessment. Then, an appraisal tool for Cross-Sectional Studies (AXIS) was used to assess the risk of bias.

The analysis was conducted using CMA version 3 software. Statistical heterogeneity was assessed using the $\mathrm{I}^{2}$ statistic and the study would be considered to have a high degree of heterogeneity if the value was $>75 \%$.

\section{Results}

The literature search, reviews, and reasons for study exclusion are described in Figure 1.

Critical analysis of five studies showed good quality reports and study designs. Those studies showed no bias in initial data collection; thus,

Table 1 Description of Studies Included in Analysis

\begin{tabular}{|c|c|c|c|c|c|c|c|}
\hline \multirow{2}{*}{ Study } & \multirow{2}{*}{ Year } & \multirow{2}{*}{$\begin{array}{c}\text { Number of } \\
\text { Patients }\end{array}$} & \multirow{2}{*}{ Population } & \multicolumn{3}{|c|}{ ACS Type } & \multirow{2}{*}{ Study Type } \\
\hline & & & & STEMI & NSTEMI & UAP & \\
\hline Duran & 2011 & 246 & ACS & $\begin{array}{c}97 \\
(39,4 \%)\end{array}$ & $\begin{array}{c}94 \\
(38,2 \%)\end{array}$ & $\begin{array}{c}55 \\
(22,4 \%)\end{array}$ & Cross sectional \\
\hline Qureshi & 2013 & 100 & Male-ACS & $\begin{array}{c}46 \\
(46 \%)\end{array}$ & $\begin{array}{c}50 \\
(50 \%)\end{array}$ & $\begin{array}{c}4 \\
(4 \%)\end{array}$ & Cross sectional \\
\hline Pramanik & 2015 & 82 & ACS & $\begin{array}{c}47 \\
(57,3 \%)\end{array}$ & $\begin{array}{c}24 \\
(29,3 \%)\end{array}$ & $\begin{array}{c}11 \\
(13,4 \%)\end{array}$ & Cross sectional \\
\hline $\mathrm{Ma}$ & 2016 & 93 & ACS & $\begin{array}{c}34 \\
(36,5 \%)\end{array}$ & $\begin{array}{c}29 \\
(31,2 \%)\end{array}$ & $\begin{array}{c}30 \\
(32,3 \%)\end{array}$ & Cross sectional \\
\hline Gaubert & 2018 & 80 & NSTEMI & - & $\begin{array}{c}48 \\
(60 \%)\end{array}$ & $\begin{array}{c}32 \\
(40 \%)\end{array}$ & Cross sectional \\
\hline
\end{tabular}


DH Prasetyo et al: Correlation between Serum Uric Acid Level and Severity of Coronary Artery Stenosis in Patients with Acute Coronary Syndrome

Table 2 Data Characteristics of Studies on Correlation between Uric Acid and Gensini Score

\begin{tabular}{lccccccc}
\hline \multicolumn{1}{c}{ Study } & Sample & r & $\mathbf{9 5 \%}$ CI & Z & p & \multicolumn{2}{c}{ Weight (\%) } \\
\hline size & & & & & & Fixed & Random \\
\hline Guran et al., 2011 & 246 & 0,452 & $0,347-0,546$ & 7,595 & 0,000 & 41.47 & 21.31 \\
Maubert et al., 2018 et al., 2016 & 80 & 0,738 & $0,619-0,824$ & 8,302 & 0,000 & 13.14 & 19.43 \\
Pramanik et al., 2015 & 93 & 0,760 & $0,658-0,835$ & 9,451 & 0,000 & 15.36 & 19.80 \\
Qureshi et al., 2013 & 100 & 0,215 & $0,019-0,394$ & 2,147 & 0,032 & 16.55 & 19.96 \\
Fixed effects & 601 & 0,519 & $0,458-0,576$ & 13,931 & $<0,001$ & 100.00 & 100.00 \\
Random effects & 601 & 0,548 & $0,328-0,711$ & 4,397 & $<0,001$ & 100.00 & 100.00 \\
\hline
\end{tabular}

they were included in this systematic review and meta-analysis. Details on these studies are described in Table 1.

The systematic review of the five articles showed a positive correlation between uric acid level and severity of coronary artery stenosis (Gensini score) in ACS patients. ${ }^{6,9-12}$ the relationship between SUA and severity of coronary atherosclerosis evaluated via endothelial dysfunction using peripheral arterial tone (PAT The secondary outcome demostrated that compared to normouricemia, hyperuricemia in ACS patients was associated with severity, wound area, and total occlusion number. ${ }^{6,10-12}$ number of diseased vessels, critical lesions and total occlusions on coronary angiogram. Results: Mean age of normouricemic group ( $n=59$ Results of the systematic review presented that the five studies were qualified to be analyzed using the the CMA3 program to evaluate the correlation

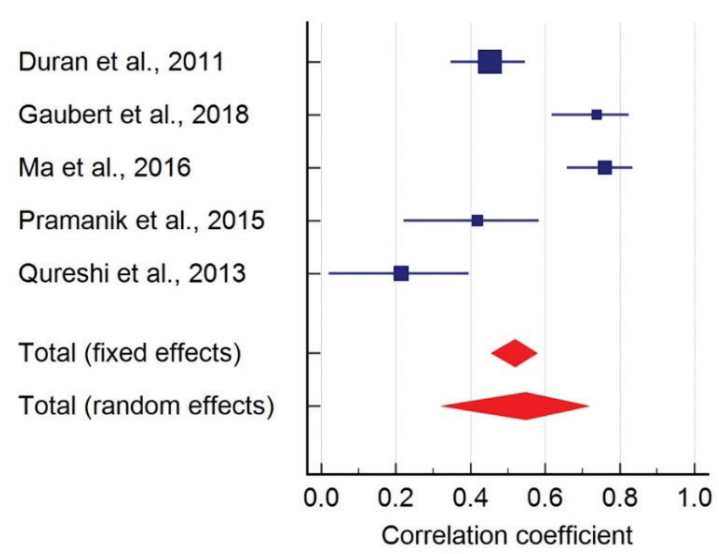

Figure 2 Forest Plot of Correlation between Uric Acid and Gensini Score between uric acid level and Gensini score. The total number of subjects included in these studies was 601 and the data characteristics of each study are presented in Table 2.

Variance analysis was performed to determine whether the studies were heterogeneous or homogenous. Studies were classified as heterogeneous if $\mathrm{p}$-value $<0.05$ or $\mathrm{I}^{2}>75 \%$ in the heterogeneity test. After testing, studies included in this meta-analysis were found to be heterogenous, with $\mathrm{I}^{2}=90.5 \%$ and $\mathrm{p}<0.001(95 \%$ CI). Therefore, the model used to quantify pooled effect was the random effect model.

The Forest plot (Figure 2) showed the correlation between each study (black box) and its confidence interval (horizontal line). In addition, pooled correlations were depicted as diamond (red). A p-value of the forest plot was $<0.05$, resulting in the null hypothesis being rejected. Therefore, there was a positive correlation between uric acid level and severity of artery stenosis, with a correlation coefficient of 0.584 , which could be categorized as moderate correlation. Also, the p-value in the significance test was 0.001, implying that the association between the two variables was significant.

The quality assessment of the studies also considered the risk of bias. Report and design quality of all studies were classified as good according to the AXIS tool and all studies showed no initial bias. In terms of publication bias, because there were fewer than ten included studies, the utility of funnel plots to assess publication bias was limited as the power of the tests would be considered too low to distinguish chance from the actual asymmetry. The regression method $(p=0.568)$ and rank correlation method $(p=0.462)$ of this metaanalysis provided a more objective means to 
Table 3 Rank Correlation and Regression of Funnel pPot

Rank Correlation Method

\begin{tabular}{cccc}
\hline $\mathrm{p}$-value & Rank Correlation & $\mathrm{p}$-value & Regression coeficient \\
\hline 0,462 & 0,735 & 0,568 & 0,639 \\
\hline
\end{tabular}

identify the presence of publication bias than a highly subjective visual inspection of the funnel plot (Table 3). There was no publication bias identified in this meta-analysis.

\section{Discussion}

This systematic review and meta-analysis is able to prove the correlation and comparability of uric acid and severity of coronary artery stenosis (Gensini score). Gensini score assessment gives weight to the closeness of the lesion in the left main coronary artery in addition to the stenosis degree, which leads to the maximum score. Therefore, the final score reflects the severity of coronary artery arteriosclerosis since it summarizes the cumulative effects of all lesions. The results of this systematic review and metaanalysis are obtained from SKA patients with higher mean uric acid levels and in line with the findings of Fromonot et al. stating that the SUA levels are higher in ACS in comparison to chronic coronary syndrome (CCS). ${ }^{13}$ Elevated SUA levels are associated with side effects and mortality in patients with IMA, as well as with the severity and mortality of acute CAD. Also, increased levels of SUA are associated with an increased risk of subsequent clinical events and mortality in patients with CCS. Increase in the SUA level, even when it is only in a slight increase out of the normal range (hyperuricemia), has started to cause a significant increase in the short-term mortality of patients with STEMI and patients undergoing PCI. ${ }^{4}$ The study of Ma et al. reported an increase in SUA levels related to the clinical type of CAD. ${ }^{12}$ These results are in line with the research from Fromonot et al., reporting that patients with CAD have increased SUA levels compared to healthy people. ${ }^{13}$

This systematic evaluation and meta-analysis also described the correlation coefficients of SUA levels with moderate significant association to the severity of coronary artery stenosis. The magnitude of the determination coefficient ( $R$ square) is 0.300 or equal to $30 \%$. This means that the SUA level variable simultaneously influences the severity of coronary artery stenosis by
$30 \%$, while the remaining $70 \%$ is processed by other variables aside from other risk factors for atherosclerosis, both modified (such as dyslipidemia, smoking, Diabetes Mellitus/ insulin resistance, hypertension, chronic kidney disease (CKD), metabolic syndrome, systemic inflammation) and unmodified (such as age, genetic and hereditary, and male gendermale). ${ }^{5}$ Thus, increasing level of SUA is only considered as an adaptation response to try to prevent atherosclerosis due to the antioxidant properties of gout. Therefore, the SUA level can be considered a risk factor for atherosclerosis. This supports several studies that have revealed that increased levels of SUA are only considered an adaptation response as trial prevention against atherosclerosis due to the antioxidant properties of gout. ${ }^{4}$

Uric acid (UA) is the end product of purine metabolism in humans and great apes. The UA acts as an antioxidant and accounts for $50 \%$ of the total antioxidant capacity of biological fluids in humans. When it presents in the cytoplasm of the cells or acidic/hydrophobic milieu in atherosclerotic plaques, UA converts into a prooxidant agent and promotes oxidative stress. Through this mechanism, it participates in the pathophysiology of human disease, including CVD. Although the causality in the relationship between UA and CVD remains unproven, UA may be pathogenic and participates in the pathophysiology of CVD by serving as a bridging mechanism, mediating (enabling) or potentiating the deleterious effects of cardiovascular risk factors in vascular and myocardium tissue. ${ }^{5}$

The correlation between SUA and the severity of stenosis is made possible through the ACS pathomechanism process, which causes ischemia and acute myocardial necrosis due to severe coronary artery stenosis and even blockage. This ischemic state will induce anaerobic metabolism, which leads to low ATP production and the failure of ion exchange channels that disrupt enzymatic activity in the cytoplasm. Mitochondrial damage and electrolyte imbalance in the state of reperfusion increase oxidative stress through three primary systems, namely nicotinamide adenine 
dinucleotide phosphate (NADPH) oxidase, nitric oxide synthase (NOS), and xanthine oxidase. ${ }^{14}$ This increase in the xanthine oxidase system will further induce the production of reactive oxygen species (ROS) by oxidizing hypoxanthine to xanthine, then xanthine to uric acid, which in turn will cause a surge in purine metabolites in the circulation, leading to hyperuricemia..$^{15}$ Thus, hyperuricemia has also been studied as a marker of poor prognosis and increased mortality in general, as well as other comorbidities found in CAD patients. The mechanism of hyperuricemia's role in the pathogenesis of atherosclerosis in ACS patients is made possible through the NF$\kappa B$ pathway that mediates endothelial disorders and vascular dysfunction, which are induced by hyperuricemia through reduction of nitric oxide (NO) and expression of pro-inflammatory cytokines. The link between activated NF- $\kappa \mathrm{B}, \mathrm{NO}$ reduction, maladaptive immune response, and vascular dysfunction enables the development of new therapeutic strategies to protect against cardiovascular disease. ${ }^{16}$ Further studies are required to reduce the effects of hyperuricemia with the severity of coronary artery stenosis. Thus, these results can support the notion of SUA level as a risk factor for atherosclerosis.

In conclusion, correlation between SUA and the severity of coronary artery stenosis in ACS is evident based on the metaanalysis in this study.

\section{References}

1. Chan MY, Du X, Eccleston D, Ma C, Mohanan PP, Ogita M, et al. Acute coronary syndrome in the Asia-Pacific region. Int J Cardiol. 2016;202:861-97.

2. Anderson JL, Morrow DA. Acute myocardial infarction. N Engl J Med. 2017;376(21):205364.

3. Kuwabara M. Hyperuricemia, cardiovascular disease, and hypertension. Pulse. 2016;3(34):242-52.

4. Larsen TR, Gerke O, Diederichsen ACP, Lambrechtsen J, Steffensen FH, Sand NP, et al. The association between uric acid levels and different clinical manifestations of coronary artery disease. Coron Artery Dis. 2018;29(3):194-203.

5. Ndrepepa G. Uric acid and cardiovascular disease. Clin Chim Acta. 2018;484:150-63.

6. Qureshi AE, Hameed S, Noeman A. Relationship of serum uric acid level and angiographic severity of coronary artery disease in male patients with acute coronary syndrome. Pakistan J Med Sci. 2013;29(5):1137-42.

7. Lan M, Liu B, He Q. Evaluation of the association between hyperuricemia and coronary artery disease A STROBEcompliant article. Med (United States). 2018; 97(44):e12926.

8. George J, Kataria SP, Isser HS. The corelation of serum uric acid with risk factors and severity of coronary artery disease (CAD) in acute coronary syndrome. International Journal of Contemporary Medicine Surgery and Radiology. 2019;4(4):D107-12.

9. Gaubert $M$, Marlinge $M$, Alessandrini $M$, Laine M, Bonello L, Fromonot J, et al. Uric acid levels are associated with endothelial dysfunction and severity of coronary atherosclerosis during a first episode of acute coronary syndrome. Purinergic Signal. 2018;14(2):191-9.

10. Duran M, Kalay N, Akpek M, Orscelik O, Elcik D, Ocak A, et al. High levels of serum uric acid predict severity of coronary artery disease in patients with acute coronary syndrome. Angiology. 2012;63(6):448-52.

11. Pramanik S, Mondal K, Dey AK, Mandal PK, Das SK, Momin TW, et al. A study of angiographic severity in patients with coronary artery disease and hyperuricemia. Asian J Med Sci. 2015;7(2):1-4.

12. Ma QQ, Yang XJ, Yang NQ Liu L, Li XD, Zhu $\mathrm{K}$, et al. Study on the levels of uric acid and high-sensitivity C-reactive protein in ACS patients and their relationships with the extent of the coronary artery lesion. Eur Rev Med Pharmacol Sci. 2016;20(20):4294-8.

13. Fromonot J, Deharo P, Bruzzese L, Cuisset T, Quilici J, Bonatti S, et al. Adenosine plasma level correlates with homocysteine and uric acid concentrations in patients with coronary artery disease. Can J Physiol Pharmacol. 2016;94.(3):272-7.

14. Wu MY, Yiang GT, Liao WT, Tsai APY, Cheng YL, Cheng PW, et al. Current Mechanistic Concepts in Ischemia and Reperfusion Injury. Cell Physiol Biochem. 2018;46(4):1650-67.

15. Rabadi MM, Kuo MC, Ghaly T, Rabadi SM, Weber M, Goligorsky MS, et al. Interaction between uric acid and HMGB1 translocation and release from endothelial cells. Am J Physiol Renal Physiol. 2012;302(6):F73041.

16. Zhen H, Gui F. The role of hyperuricemia on vascular endothelium dysfunction. Biomed Rep. 2017;7(4):325-30. 